\title{
Quantitative study on shoreline changes and Erosion Hazard assessment: case study in Muriganga-Saptamukhi interfluve, Sundarban, India
}

\author{
Abhishek Ghosh ${ }^{1} \cdot$ Sutapa Mukhopadhyay ${ }^{1}$
}

Received: 21 March 2016/Accepted: 12 April 2016/Published online: 20 April 2016

(C) Springer International Publishing Switzerland 2016

\begin{abstract}
Quantitative techniques, statistical methods and mathematical rules make the geospatial analysis more systematic, accurate and precise. In order to measure the intensity of the ongoing processes on the earth surface, evaluate the spatio-temporal changes in geographical attributes, highlight the principal factors for any geographic events and to identify the future possibilities, quantitative techniques are for most dependable. In the present article sequential changes of the shoreline, spatio-temporal extent of erosion and depositional processes of Sundarban region, West Bengal, India, have been measured following the selected quantitative techniques. The Sundarban is one of the most dynamic geomorphic units in the earth surface, situated in the northern apex of Bay of Bengal. The region has formed, sculptured and modified due to continuous sedimentation of the Ganga and the Brahmaputra systems, intense tidal hydro dynamic behavior, climatic disturbances and anthropogenic activities. In the last two century most of the parts of the active Sundarban delta has being reclaimed and occupied with dense rural settlements, most of the peoples are engaged in agriculture based rural economy, hence substantial erosion and successive regressive changes in the area have an unconstructive impact on the dwelling communities. In order to examine the net shoreline changes, average rate of end point changes and extent of erosion and depositional processes Survey of India toposheets of 1920, 1921, 1922, 1923, US Army toposheets of 1955, Survey of India toposheets
\end{abstract}

Abhishek Ghosh

abhishekghosh20.3.90@gmail.com

1 Department of Geography, Visva-Bharati, Santiniketan, West Bengal 731235, India of 1967, 1968, 1969 and IRS P6 LISS IV satellite images of 2014 have been used. Finally erosion hazard zones have been identified will help of net area changes of the each geomorphic units to access the spatial variation of erosion hazard intensity. Quantitative model has been prepared on the basis of multi temporal data of Muriganga-Saptamukhi interfluve area of western Sundarban which can be applied to the other parts of Sundarban region.

Keywords Deposition - Erosion - Erosion hazard assessment $\cdot$ Estuary $\cdot$ Shoreline changes $\cdot$ Sundarban

\section{Introduction}

Sundarban is a vast active deltaic tract of Asia. Geomorphological attributes, hydrological behavior that configures this mysterious landscape is very dynamic and sensitive. Morphologically this landscape is the product of successive deposition by the Ganga and Brahmaputra River. Since the formation of this geomorphic region the area especially its marginal parts are getting affected by regional tectonic set up, fluvial and coastal hydrodynamic behaviors, climatic extremities and human interferences. Strong tidal activities, long shore current and wave have constantly been modified, shaped and reshaped the marginal shorelines in this active estuarine delta through hydro-geomorphological processes like erosion and deposition (Chakrabarti 1995; Bandyopadhyay et al. 2004; Raju et al. 2010; Jana et al. 2012; Chakraborty 2013; Das et al. 2013; Addo 2015). Once it was marshy forested immature low land, successively has evolved by hydrological processes but later through consequential phases of reclamation present Sundarban, became the home of 
millions (Mukherjee, 2002). In this fatal platform, dwellers are living in a misconception with nature in vulnerable condition in the form of erosion and rapid embankment breaching. Sundarban region is demarcated by the river Hooghly on the West, the Bay of Bengal on the South, and the Ichamati-Kalindi-Raimongal Rivers on the east and the Dampier-Hodges line on the North. Sundarban region comprises of nineteen administrative blocks (sixteen police stations) of North 24-Parganas and South 24-Parganas Districts of the State of West Bengal. The land area measures about $9629^{2} \mathrm{~km}$, of which $4493^{2} \mathrm{~km}$ is inhabited by people and the rest is Reserve Forest. Approximate population of Sundarban region is 45 lakhs. About $80 \%$ of the population in Sundarbans is based on agriculture (Hazra et al. 2010; Danda et al. 2011; Ghosh 2012). So the progressive land losses become economic hindrance for their sustenance (Jana et al. 2012; Das et al. 2013; Chakraborty 2013; Bandyopadhyay et al. 2014).

\section{Geo-tectonic setup of the Bengal basin}

The Sundarban region is the tidally active and one of the most dynamic deltaic regions in the world. Flat sandy beach, tidal marsh, mud flat, creeks are the geomorphic signatures of this landscape (Paul 2002; Das 2006; Rahman 2012; Udo-Akuaibit 2014; Weichselgartner and Pigeon 2015). The region is situated in the northern apex of Bay of Bengal. The area has been successively developed by the sediment deposition by the Ganga and Brahmaputra river (Mikhailov and Dotsenko 2007; Sarkar et al. 2009; Jha and Bairagya 2011). Due to the tectonic set up the Bengal basin has been tilted towards east. So the Ganga River has successively changed its course towards east from its historical past. Now the river used to flow eastward direction. Due to the shifting course of the river Ganga Sundarban region in the western part of the Bengal basin has started to suffer from the paucity of fresh water discharge and sedimentation. Auto compaction of loosely attached sediments and gradual land subsidence is also another prominent geomorphic events occurring in this region (Chakrabarti 1995; Islam et al. 1999; Stanley and Hait 2000; Goodbred et al. 2003; Alam et al. 2003; Islam and Gnauck 2008). In the western part of Sundarban region Hugli and Haringhata Rivers carry some amount of fresh water (Bandyopadhyay and Bandyopadhyay 1996; Bandyopadhyay 2007). Sweet water flow along the Hugli River is very much maintained by the Farakka barrage in the northern apex of the Ganga delta. So the tectonic activities and shifting river courses have an impact in the lower segment of the delta in terms of sediment supply as well as fresh water supply.

\section{Nature of the tidal estuary}

Sundarban is a macro tidal (Tidal range $>4 \mathrm{~m}$ ) active delta of Bengal basin. The rivers of the upper part of the delta have ended in the low marshy wetlands and they have not any connection with the Ganga or any other sweet water sources. Hence the hydrological characters of almost all the rivers are controlled by the tidal rush. The shape of the estuary is also important in shaping the face of the land masses. The funnel shape mouth and land ward narrowing of the channel is mainly responsible for the tidal asymmetry, due to such condition high tidal water enters in the estuary but the low tidal water cannot properly pass out, this flow variation has key role to damage the bank line in the estuarine belt. The velocity and the duration of flood tide remains very high then ebb tide which significantly damaged exposed embankments. So the land word increase in tide level and the tidal velocity have extremely damaged the marginal exposed low lying areas (Bandyopadhyay and Nandy 2011). Similarly the directions of tidal flow, channel forms and river bed configuration have a strong connection with the extent of erosion and deposition patches (Paul 2002; Das 2006).

\section{Climatic extremities in the Sundarban}

The region is extremely affected by the strong cyclonic activities. The surface temperature, sea level temperature has progressively changed since last decade which has energized the cyclonic activities over time (Bandyopadhyay 1997; Hazra et al. 2010; Danda et al. 2011; Ghosh, 2012; Mallick and Vogt 2015). The last decades has witnessed some immense cyclones namely Mala (2006), Sidr (2007), Nargis (2008), Aila (2009) and many others extremities collectively massacred the marginal parts of the Sundarban (Ghosh 2012). Generally it has observed during south west monsoon season in India tidal bores have generated in these regions, when they co insides with the cyclonic events the situations become very severe. The maximum concentration of cyclonic activities took place during June to October month. During this time the strong surges developed over this region due to intensive low pressure which significantly damaged the marginal embankment every year. The situation becomes extreme when the cyclonic active coincides with full moon. The enormous tide generated during this period massacred the flat coastal belts and low lying marginal parts of entire Sundarban region.

\section{Human interruption in the Sundarban}

The face of the low lying marshy forested land of Sundarban region has been altered over time by human 
encroachment. The Britishers initiated rapid reclamation over this region with the help of local Zamindars (Land loads of pre independence India) for revenue collection. The entire phrases of land reclamation took place in five different phrases (1770-1780, 1780-1873, 1873-1939, 1945-1951 and 1951-1971). The post independence periods have experienced galloping population growth in the Sundarban region. In the last two century intense land use alteration, harbour construction, heavy embankment construction etc. have triggered the river bed siltation process which acts as a maneuvering fact for increasing tidal level
(Bandyopadhyay and Bandyopadhyay 1996; Mukherjee, 2002; Mandal et al. 2009; Tsoukala et al. 2015; Misra and Balaji 2015; Hossain et al. 2015). The Sundarban region is one of the most dense populated region hence the human induced activities in the form of large scale deforestation, reclamation of immature low land for agriculture and commercial fisheries, development of large scale tourism activities and river jacketing through embankments have collectively influenced the natural geomorphic setup and tidal environment, which further intensified the erosion and depositional extent.

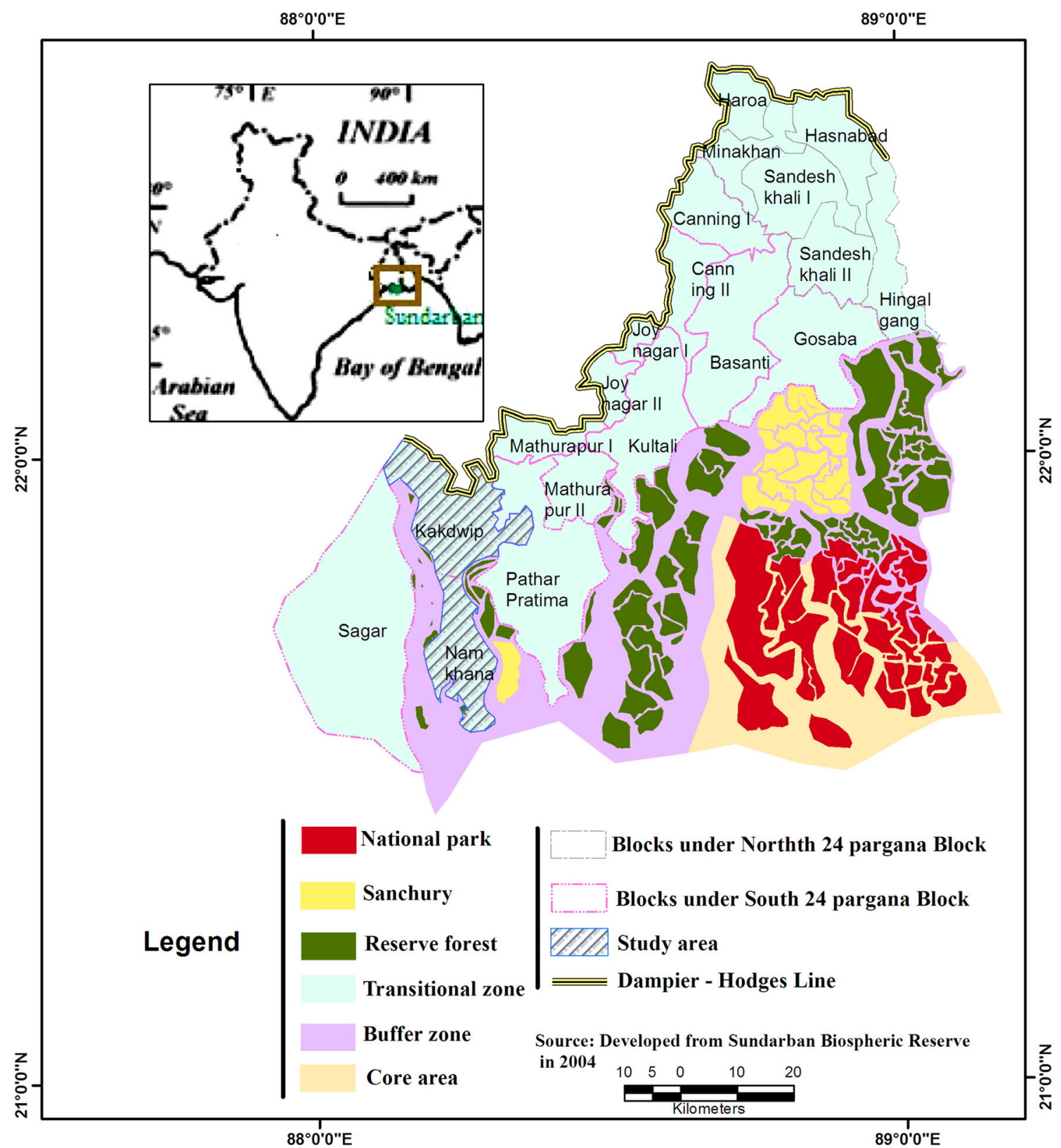

Fig. 1 Location of the study area 
Table 1 Hydro-geomorphic divisions of the area. Source: Survey of IndiaToposheets1967-1968, 1968-1969, IRS P6 LISS IV Image 2014 and field investigation 2013-2015

\begin{tabular}{|c|c|c|c|c|}
\hline $\begin{array}{l}\text { Geomorphic } \\
\text { units }\end{array}$ & Relief and slope pattern & $\begin{array}{l}\text { Nature of rivers and } \\
\text { creeks }\end{array}$ & $\begin{array}{l}\text { Active processes and morphological } \\
\text { signatures }\end{array}$ & $\begin{array}{l}\text { Active geomorphic } \\
\text { agents }\end{array}$ \\
\hline $\begin{array}{l}\text { Low lying } \\
\text { coastal flat }\end{array}$ & $\begin{array}{l}2-2.6 \mathrm{~m} \text { Flat and gentle sloping } \\
\text { towards south }\end{array}$ & $\begin{array}{l}\text { Small tidal creeks } \\
\text { connected with sea }\end{array}$ & $\begin{array}{l}\text { Erosion, deposition, shore line change, } \\
\text { Sand dune formation, sands ply, salt } \\
\text { marsh formation }\end{array}$ & $\begin{array}{l}\text { Tide, wave, long shore } \\
\text { current, seasonal } \\
\text { wind action }\end{array}$ \\
\hline $\begin{array}{r}\text { Low lying } \\
\text { tidal flat }\end{array}$ & $\begin{array}{l}2.6-3.8 \mathrm{~m} \text { Flat and gentle } \\
\text { sloping towards marginal } \\
\text { parts from inner part }\end{array}$ & $\begin{array}{l}\text { Tidally active rivers and } \\
\text { small creeks with } \\
\text { dynamic bank line }\end{array}$ & $\begin{array}{l}\text { Erosion, deposition, bank line change, } \\
\text { flood and prolonged water stagnation }\end{array}$ & Tide, surge \\
\hline $\begin{array}{l}\text { Low lying } \\
\text { Island }\end{array}$ & $\begin{array}{l}3.9-2 \mathrm{~m} \text { Flat and gentle sloping } \\
\text { towards south }\end{array}$ & $\begin{array}{l}\text { Surrounded by large rivers } \\
\text { and creeks }\end{array}$ & $\begin{array}{l}\text { Erosion, deposition of bank line, } \\
\text { shifting sand dune, sands ply, salt } \\
\text { marsh formation }\end{array}$ & $\begin{array}{l}\text { Tide, wave, surge, } \\
\text { seasonal wind action }\end{array}$ \\
\hline $\begin{array}{l}\text { Elevated } \\
\text { tidal flat }\end{array}$ & $\begin{array}{l}\text { 3-6 m Slightly elevated and } \\
\text { gentle sloping towards south }\end{array}$ & $\begin{array}{l}\text { Moderately stable small } \\
\text { tidal creeks }\end{array}$ & Erosion, deposition, bank line change & Tide, surge \\
\hline
\end{tabular}

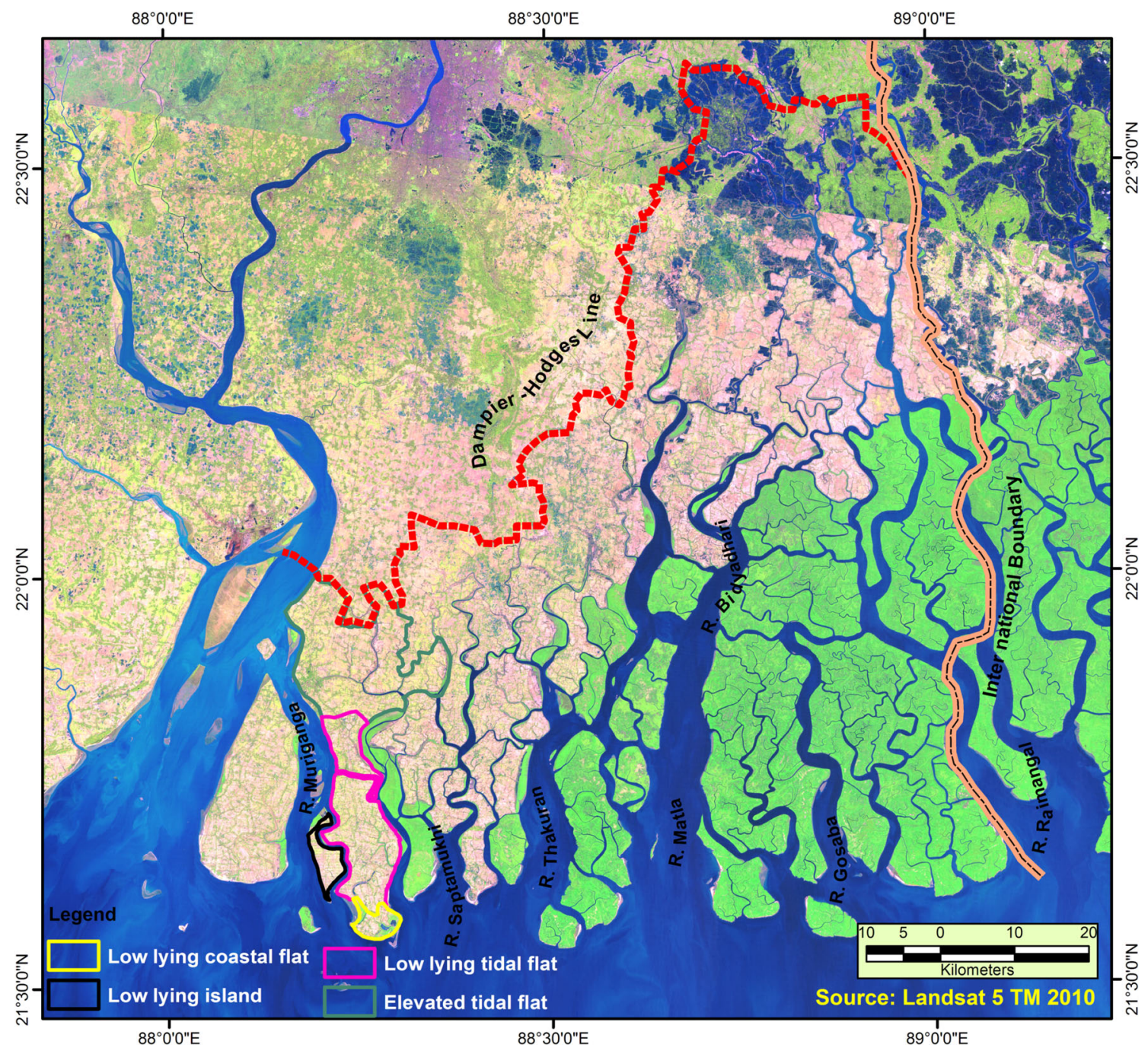

Fig. 2 Geomorphic divisions of the study area within entire Sundarban delta 
Table 2 Multi temporal data base for the study

\begin{tabular}{|c|c|c|c|c|c|c|c|}
\hline \multicolumn{5}{|l|}{ Maps } & Scale & Survey year & Remarks \\
\hline \multicolumn{5}{|c|}{ Survey of India Toposheets (79 c/1, 79c/2, 79c/5, 79c/6) } & $1: 50,000$ & $1920-1921,1922-1923$ & Detection of shoreline \\
\hline \multicolumn{5}{|c|}{ US Army Toposheet (NF 45-11) } & $1: 250,000$ & 1955 & Detection of shoreline \\
\hline \multicolumn{5}{|c|}{ Survey of India Toposheets $(79 \mathrm{c} / 1,79 \mathrm{c} / 2,79 \mathrm{c} / 5,79 \mathrm{c} / 6)$} & $1: 50,000$ & 1967-1968, 1968-1969 & Detection of shoreline \\
\hline Image & $\begin{array}{l}\text { Date of } \\
\text { acquisition }\end{array}$ & Path & Row & $\begin{array}{l}\text { No. of } \\
\text { bands }\end{array}$ & $\begin{array}{l}\text { Spatial resolution } \\
(\mathrm{m})\end{array}$ & Remarks & \\
\hline \multicolumn{8}{|l|}{ Satellite image } \\
\hline $\begin{array}{l}\text { Landsat-5 } \\
\text { TM }\end{array}$ & $06 / 02 / 2010$ & 138 & 45 & 7 & 30 & \multicolumn{2}{|c|}{$\begin{array}{l}\text { Detection of general geomorphic set up of the whole } \\
\text { Sundarban region }\end{array}$} \\
\hline $\begin{array}{l}\text { Landsat-5 } \\
\text { TM }\end{array}$ & $06 / 02 / 2010$ & 138 & 44 & 7 & 30 & \multicolumn{2}{|c|}{$\begin{array}{l}\text { Detection of general geomorphic set up of the whole } \\
\text { Sundarban region }\end{array}$} \\
\hline $\begin{array}{l}\text { IRS P6 LISS } \\
\text { IV }\end{array}$ & $18 / 02 / 2014$ & 108 & 57 & 3 & 5.8 & \multicolumn{2}{|l|}{ Detection of shoreline } \\
\hline
\end{tabular}

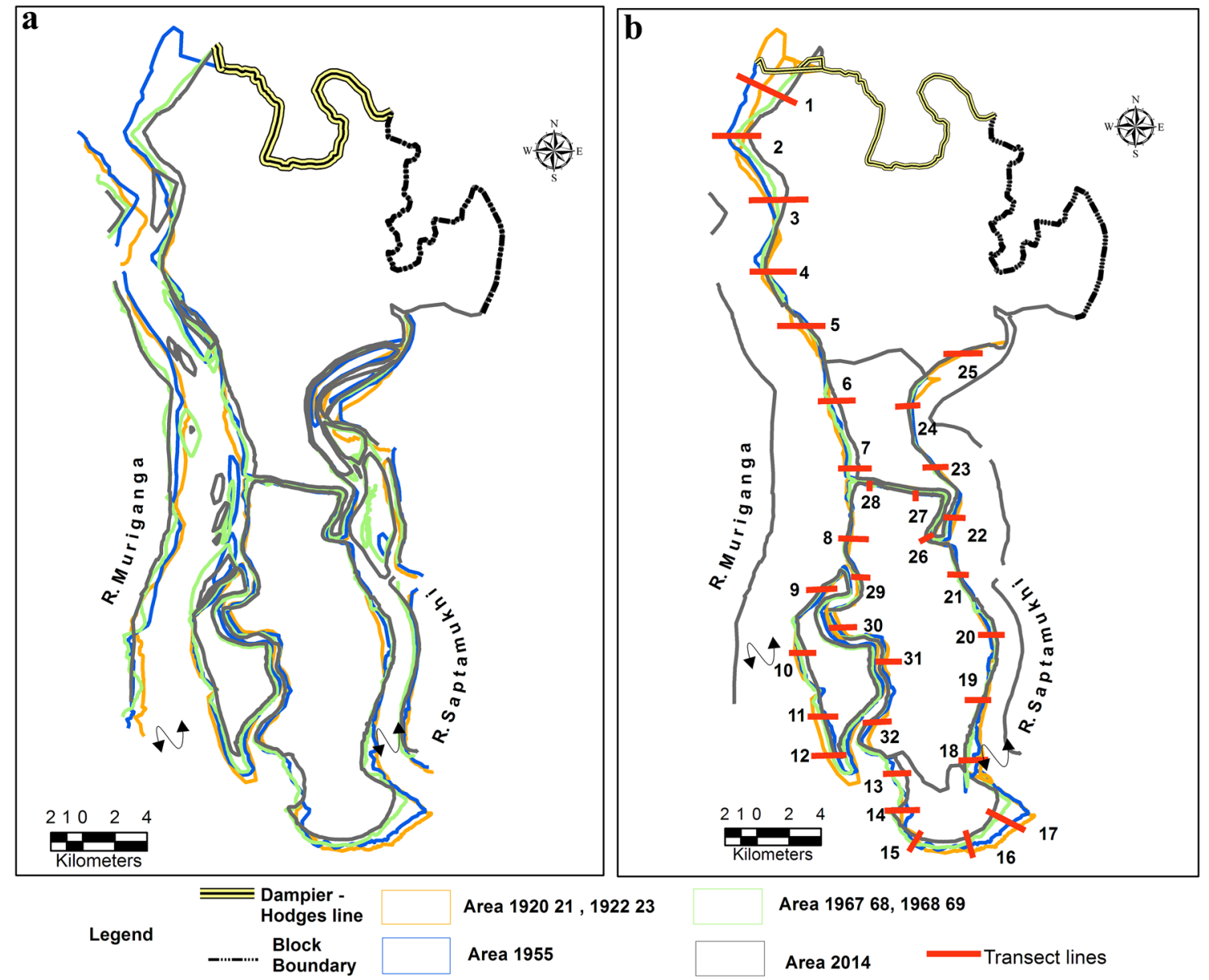

Fig. 3 a, b Superimposition of shorelines and distribution of transect lines

\section{Selection of the study area}

In the present paper for determining of erosion hazard zone using net shoreline changes, spatio-temporal analysis of erosional and depositional processes on the quantitative analysis has taken on the selected area on MurigangaSaptamukhi interfluve of western estuarine Sundarban using multi temporal data base. The region has distinct 
Table 3 Net changes and Average changes of shoreline over time. Source: Survey of IndiaToposheets 1920-1921, 1922-1923, 1967-1968, 1968-1969, IRS P6 LISS IV Image 2014 and field

\begin{tabular}{|c|c|c|c|c|c|c|c|}
\hline \multirow[t]{3}{*}{ No. of transects } & \multicolumn{6}{|c|}{ Net shoreline change (in meters) } & \multirow{3}{*}{$\begin{array}{l}\text { Average end point rate of } \\
\text { shoreline change (1920-1921, } \\
\text { 1922, 1923-2014) }\end{array}$} \\
\hline & \multicolumn{2}{|c|}{ 1922-1955 } & \multicolumn{2}{|c|}{$1955-1968$} & \multicolumn{2}{|c|}{ 1968-2014 } & \\
\hline & $\begin{array}{l}\text { Positive } \\
\text { changes }\end{array}$ & $\begin{array}{l}\text { Negative } \\
\text { changes }\end{array}$ & $\begin{array}{l}\text { Positive } \\
\text { changes }\end{array}$ & $\begin{array}{l}\text { Negative } \\
\text { changes }\end{array}$ & $\begin{array}{l}\text { Positive } \\
\text { changes }\end{array}$ & $\begin{array}{l}\text { Negative } \\
\text { changes }\end{array}$ & \\
\hline 1. North west & & & & -1940 & & -628 & -209.333 \\
\hline 2. North west & & & & -544 & & -986 & -328.667 \\
\hline 3. North west & & -643 & & -419 & & -747 & -249 \\
\hline 4. North west & & -443 & & & 247 & & 0 \\
\hline 5. Mid west & & -1040 & 500 & & 278 & & 0 \\
\hline 6. Mid west & 237 & & 223 & & & -617 & -205.667 \\
\hline 7. Mid west & & -309 & & -391 & & -871 & -290.333 \\
\hline 8. Mid west & 286 & & 305 & & & -217 & -72.3333 \\
\hline 9. Mid west & 368 & & 393 & & & -181 & -60.3333 \\
\hline 10. South west & & -473 & & -289 & & -653 & -217.667 \\
\hline 11. South west & & -987 & & -375 & & -254 & -84.6667 \\
\hline 12. South west & & -693 & & -319 & & -762 & -254 \\
\hline 13. South & & & 260 & & & -1084 & -361.333 \\
\hline 14. South & & -699 & 1145 & & 278 & & 0 \\
\hline 15. South & 510 & & & & & -584 & -194.667 \\
\hline 16. South & & -771 & & -413 & & -504 & -168 \\
\hline 17. South & & -741 & & -884 & & -473 & -157.667 \\
\hline 18. South east & & -295 & & -567 & & -371 & -123.667 \\
\hline 19. South east & & -204 & & -370 & & & 0 \\
\hline 20. Mid east & & -77 & 430 & & 373 & & 0 \\
\hline 21. Mid east & 117 & & & -375 & 234 & & 0 \\
\hline 22. Mid east & & -306 & & -332 & 220 & & 0 \\
\hline 23. Mid east & & -19 & & -288 & 50 & & 0 \\
\hline 24. North east & & & & -256 & & & 0 \\
\hline 25. North east & & -581 & & & & & 0 \\
\hline 26. Inner creeks & & -283 & & -217 & & -198 & -66 \\
\hline 27. Inner creeks & & -160 & & -152 & & -180 & -60 \\
\hline 28. Inner creeks & & -181 & & -152 & 260 & & 0 \\
\hline 29. Inner creeks & & -301 & & -201 & & -240 & -80 \\
\hline 30. Inner creeks & 474 & & 322 & & 240 & & 0 \\
\hline 31. Inner creeks & 375 & & 222 & & & & 0 \\
\hline 32. Inner creeks & 575 & & 624 & & & -50 & -16.6667 \\
\hline
\end{tabular}

coastal zone affected by long shore current as well as estuarine zone of strong tidal current. So this zone can be treated as the representative of the Sundarban deltaic region and the present discussed statistical methods and modes can be applied in the other parts of this region.

\section{Hydro geomorphic address of the study area}

The concerned study area is situated in the western part of Sundarban in between Saptamukhi River in east and Muriganga River in west extending from $21^{\circ} 32^{\prime} 52^{\prime \prime}$ north to $22^{\circ} 0^{\prime} 40^{\prime \prime}$ north and $88^{\circ} 7^{\prime} 7^{\prime \prime}$ east to $88^{\circ} 22^{\prime} 28^{\prime \prime}$ east (Fig. 1). Northern boundary has been demarcated by Dampier-Hodges line which distinguished tidally active Sundarban delta from mature delta in north. The flat sandy coastal land is the main geomorphological characteristics of its southern tract. The central part of the study area is low lying flat having large number of interconnected tidal creeks with low elevation between 2.6 and $3.8 \mathrm{~m}$. The northern part is slightly elevated then the rest part of the study area with 3-6 m from mean sea level. From geographical set up it is clearly visualized that in the southern 
part long shore current and strong tidal wave from Bay of Bengal dominates especially during monsoon season but inner part and northern part has been influenced by strong macro tidal current by active rivers. This unique hydrogeomorphic set up makes its marginal embankment very damage sensitive thus the entire area gets inundated by the tidal rush. The Table 1 depicts detail scenario of the morphological set up of the entire region along with major processes and active operating agents (Fig. 2).

\section{Data base and methodology}

The paper attempts to understand the spatio-temporal changes of shoreline configuration in relation to the erosion and deposition processes along with their underlying mechanisms, in the estuarine Sundarban region between Muriganga and Saptamukhi interfluve using some old toposheets of 1920-1921, 1922-1923 of survey of India, US Army Toposheets of 1955, Survey of India toposheets of 1967-1968, 1968-69 and IRS P6 LISS IV images of 2014 using Arc GIS (Arc map 10, esri) software (Table 2). Some quantitative analysis on the bank line shift and shoreline configuration have been done by the scientist from the very beginning of the last century (Bandyopadhyay et al. 2004; Raju et al. 2010; Jana et al. 2012; Rudra 2012; Chakraborty 2013; Das et al. 2013). The different erosional and depositional patches as well as the changing bank line conditions have been detected with the imposing of successive digitized layers after image to image rectification from all the toposheets and images of successive periods. Patches of erosion and deposition have been used to calculate the net areal changes in different geomorphic units (Hazra et al. 2010; Jana et al. 2012; Das et al. 2013; Hossain et al. 2015). The net areal change is the absolute difference between eroded area and deposited area. The net areal changes of different geomorphic units have been assigned in descending order to find out maximum and minimum erosion hazard intensity zones.

\section{Results and discussion}

\section{Spatio-temporal changes of shore line configuration}

The shorelines, river banks are one of the most dynamic geomorphic features over earth surface (Bandyopadhyay et al. 2004; Raju et al. 2010; Jana et al. 2012; Chakraborty 2013; Das et al. 2013; Laha and Bandyopadhyay 2013). Spatio-temporal changes of shoreline configuration of Muriganga-Saptamukhi interfluve of deltaic estuarine Sundarban region has been analyzed between 1920-1921, 1922-1923 and 2014 using transects lines and successive superimposition of shorelines and river bank (Fig. 3a). In
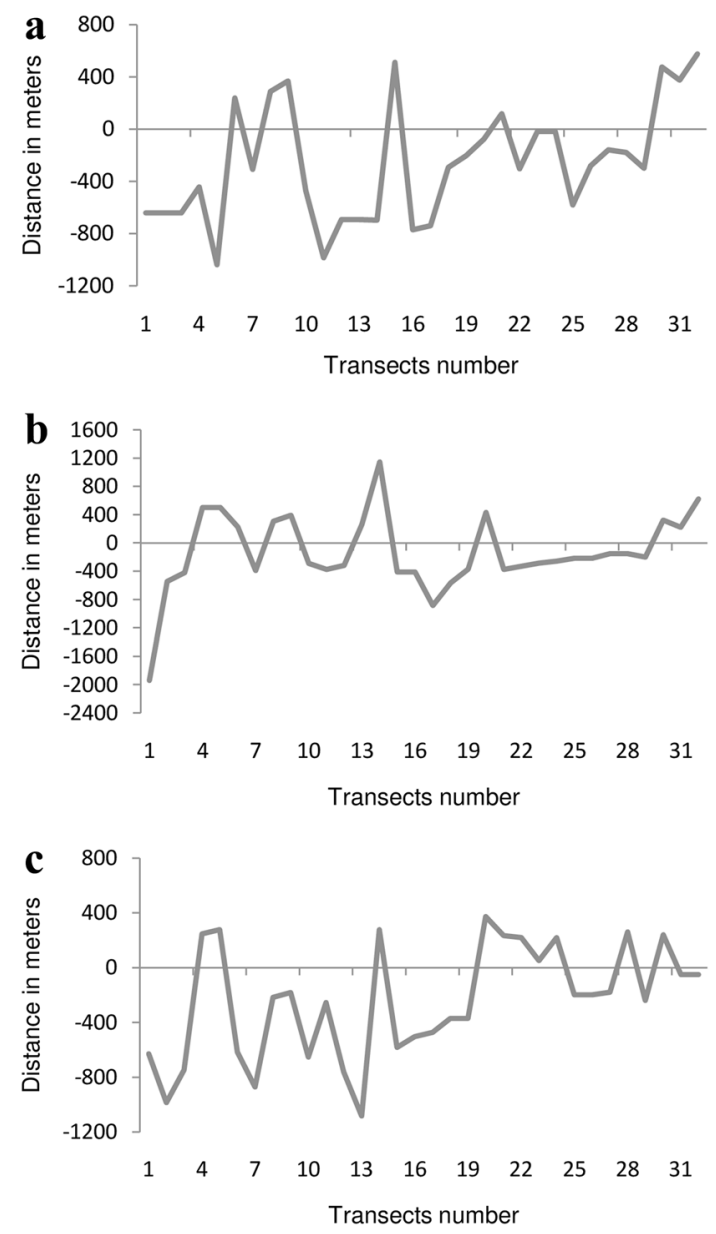

Fig. 4 a, b, c Net shoreline movement in different periods

order to understand the spatio-temporal changing pattern of shoreline configuration net shoreline movement, end point rate have been employed over transects map (Fig. 3b).

\section{Net shoreline movement}

Net shoreline movement is a statistical measure of the distance between two successive shorelines (Jana et al., 2012; Das et al. 2013) (Table 3). The whole movement has been analyzed in three phases from 1920-1921 to 2014.

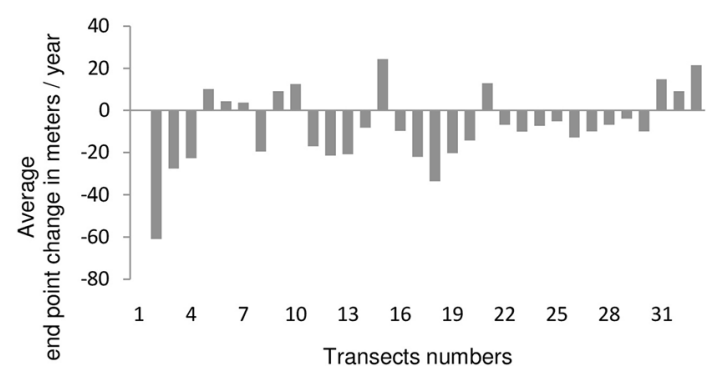

Fig. 5 Average end point change rate of shorelines 
Table 4 Areal extent of erosion and deposition over time. Source: Survey of IndiaToposheets 1920-1921, 1922-1923, 1967-1968, 1968-1969, IRS P6 LISS IV Image 2014 and Field survey

\begin{tabular}{|c|c|c|c|c|c|c|}
\hline \multirow{2}{*}{$\begin{array}{l}\text { Geomorphic } \\
\text { units }\end{array}$} & \multicolumn{2}{|c|}{ 1920-1921, 1922-1923-1955 } & \multicolumn{2}{|c|}{ 1955-1967, 1968, 1968-1969 } & \multicolumn{2}{|c|}{ 1967-1968, 1968-1969-2014 } \\
\hline & Erosion & Deposition & Erosion & Deposition & Erosion & Deposition \\
\hline $\begin{array}{l}\text { Low lying } \\
\text { coastal flat }\end{array}$ & $\begin{array}{l}\text { Entire southern } \\
\text { parts }\end{array}$ & $\begin{array}{l}\text { Patches in } \\
\text { eastern and } \\
\text { western parts }\end{array}$ & $\begin{array}{l}\text { Southern and } \\
\text { eastern parts }\end{array}$ & $\begin{array}{l}\text { Mainly along western } \\
\text { parts }\end{array}$ & $\begin{array}{l}\text { Almost entire } \\
\text { shoreline }\end{array}$ & $\begin{array}{l}\text { Some isolated patches in } \\
\text { western parts and } \\
\text { eastern parts }\end{array}$ \\
\hline $\begin{array}{l}\text { Low lying } \\
\text { Island }\end{array}$ & $\begin{array}{l}\text { Entire southern } \\
\text { parts }\end{array}$ & $\begin{array}{l}\text { Some patches in } \\
\text { north western } \\
\text { parts }\end{array}$ & $\begin{array}{l}\text { Entire southern } \\
\text { parts }\end{array}$ & $\begin{array}{l}\text { Some patches in north } \\
\text { western parts }\end{array}$ & $\begin{array}{l}\text { Entire southern } \\
\text { parts }\end{array}$ & $\begin{array}{l}\text { Some patches in north } \\
\text { western and north } \\
\text { eastern parts }\end{array}$ \\
\hline $\begin{array}{r}\text { Low lying } \\
\text { tidal flat }\end{array}$ & $\begin{array}{l}\text { North east, north } \\
\text { west and south } \\
\text { east }\end{array}$ & $\begin{array}{l}\text { South western } \\
\text { part and } \\
\text { central part }\end{array}$ & $\begin{array}{l}\text { North east, north } \\
\text { west and south } \\
\text { east }\end{array}$ & $\begin{array}{l}\text { South western part, } \\
\text { eastern part and } \\
\text { central part }\end{array}$ & $\begin{array}{l}\text { North east, north } \\
\text { west and south } \\
\text { east }\end{array}$ & $\begin{array}{l}\text { South western part, } \\
\text { eastern part and central } \\
\text { part }\end{array}$ \\
\hline $\begin{array}{l}\text { Elevated } \\
\text { tidal flat }\end{array}$ & $\begin{array}{l}\text { South western } \\
\text { part }\end{array}$ & $\begin{array}{l}\text { North western } \\
\text { part }\end{array}$ & $\begin{array}{l}\text { Almost entire } \\
\text { western part }\end{array}$ & $\begin{array}{l}\text { Some patches in } \\
\text { south western part }\end{array}$ & $\begin{array}{l}\text { Almost entire } \\
\text { western part }\end{array}$ & $\begin{array}{l}\text { Some patches in south } \\
\text { western part }\end{array}$ \\
\hline
\end{tabular}
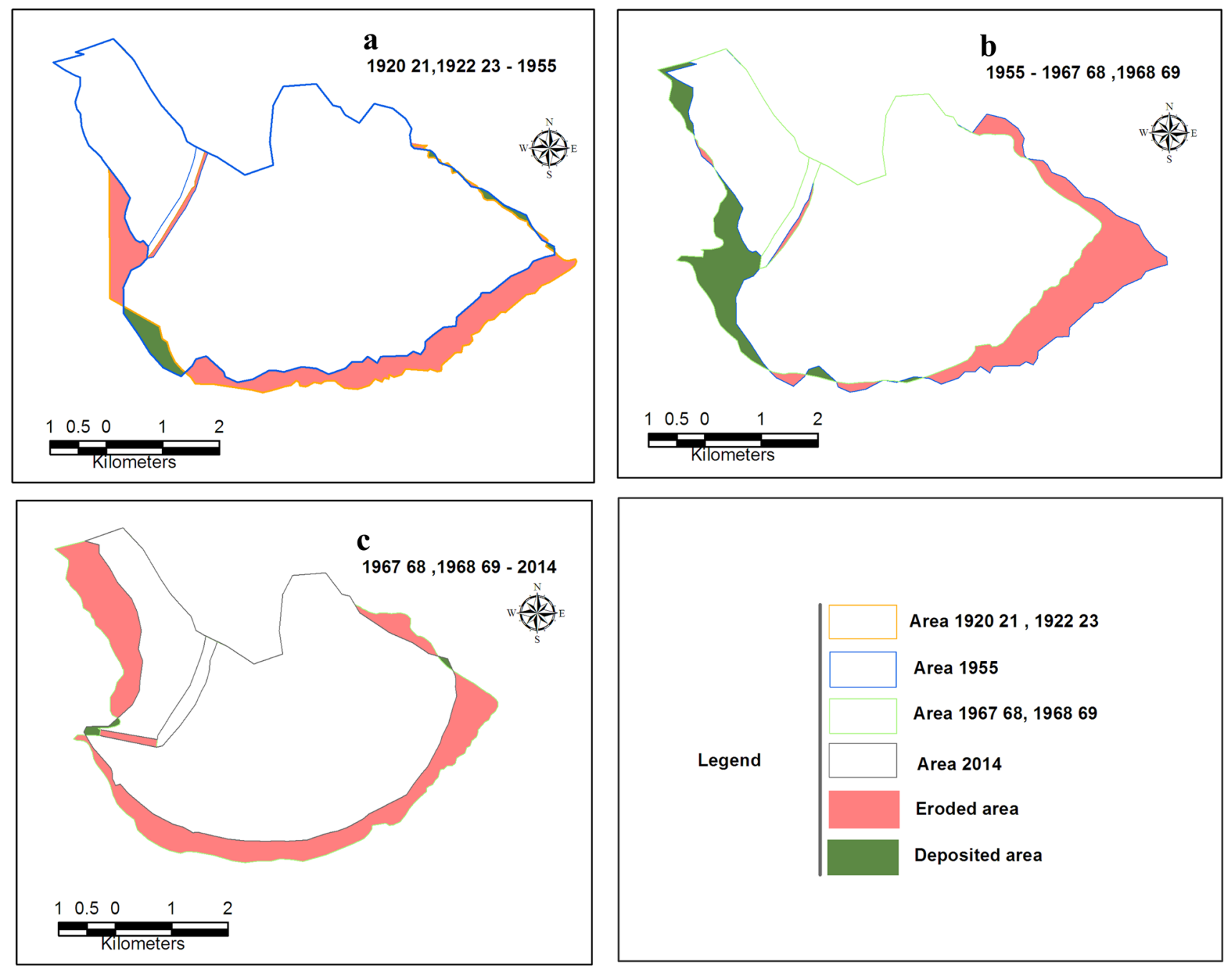

Fig. 6 Extent of erosion and deposition in low lying coastal flat region 
Between 1920-1921, 1922-1923 and 1955: During this periods $25 \%$ of the transect lines around different areas have shown positive changes $(6,8,9,15,21,30,31,32)$ whereas $75 \%$ have shown negative changes $(1,2,3,4,5$, $7,10,11,12,13,14,16,17,18,19,20,22,23,24,25,26$, 27, 28, 29) (Fig. 4a).

Between 1955 and 1967-1968, 1968-1969: during this periods $32 \%$ of the transect lines have shown positive changes $(4,5,6,8,9,13,14,20,30,31,32)$ whereas rest of the $62 \%$ transect lines have shown negative changes $(1,2$, $3,7,10,11,12,15,16,17,18,19,21,22,23,24,25,26$, 27, 28, 29) (Fig. 4b).

Between 1967-1968, 1968-1969 and 2014: this period have also shown similar patterns like previous two. Out of total transects $72 \%$ transects have shown negative changes $(1,2,3,6,7,8,9,10,11,12,13,15,16,17,18,19$, $25,26,27,29,31,32$ ) whereas only $28 \%$ transects have positive change $(4,5,14,20,21,22,23,24,28,30)$ (Fig. 4c).

\section{Average end point rate of shoreline changes}

This is another quantitative form of shoreline change measurement (Jana et al. 2012; Das et al. 2013). Here rate of changes are considered instead of absolute distance, in between two successive years (Table 3). The present work highlights an average end point change rate of shoreline between 1920-1921, 1922-1923 and 2014 to make an appraisal on average rate of changes (Fig. 5). Out of total sample transects around the study area almost $69 \%$ of the transects have experienced regressive change and only $31 \%$ of transects have shown positive changes.

\section{Erosion and depositional dilemma in different geomorphic units over time}

The present work composes a detail assessment on spatiotemporal changes of each geomorphic unit over time. Using GIS software individual vector layers of shore lines are superimposed successively to extract patches of erosion

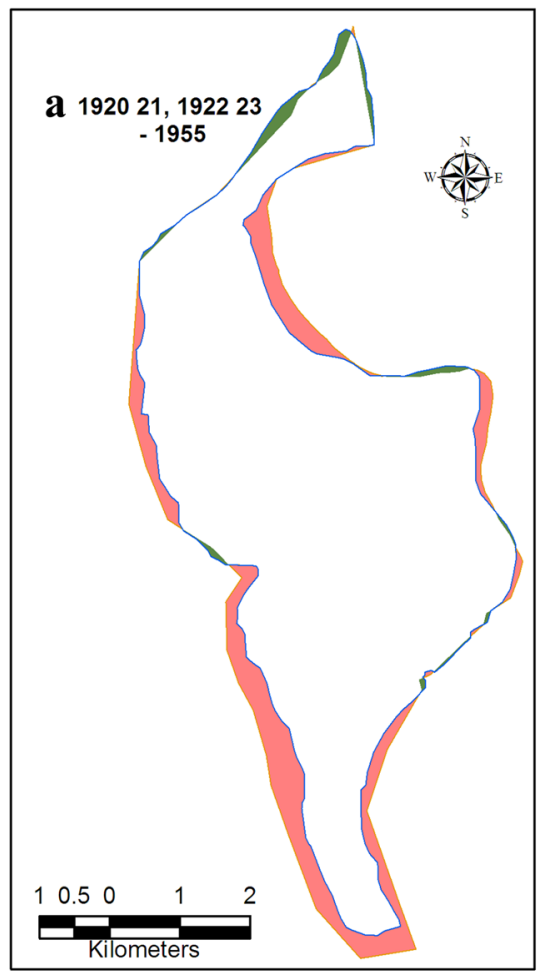

Legend

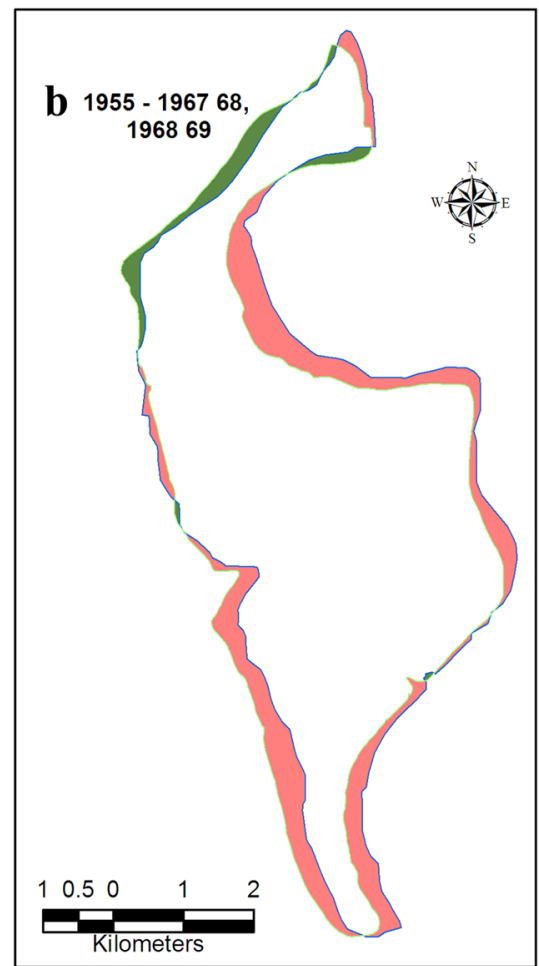

Area 192021,192223

Area 1955

Area 196768,196869

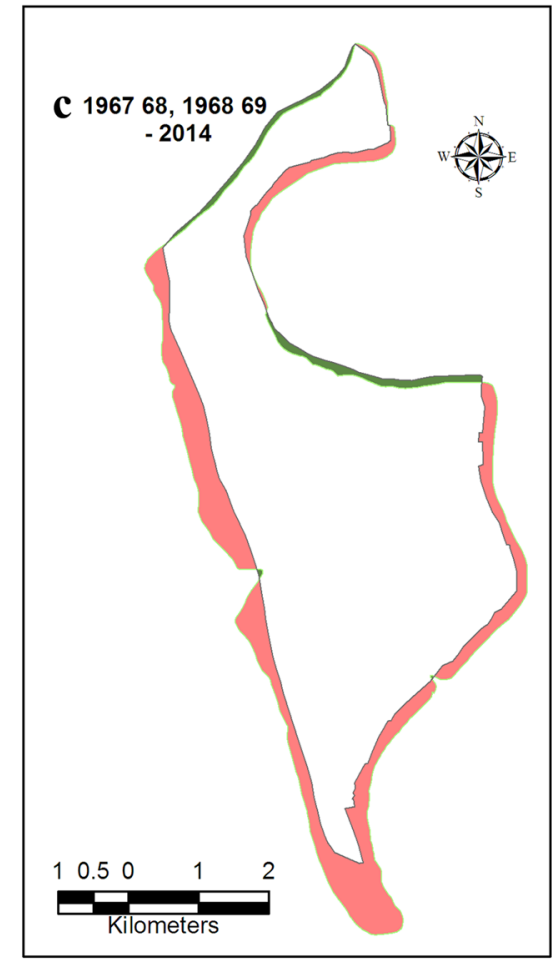

Area 2014

Eroded area

Deposited area

Fig. 7 Extent of erosion and deposition in low lying island region 
and deposition over the time (Bandyopadhyay et al. 2004). After the detail mapping of erosion and depositional extent over different geomorphic unit's net change has been formulated out to understand the direction and magnitude of temporal changes after superimposing the multi temporal maps. The resultant fact is that the total amount of land erosion exceeds the total amount of deposition, hence the entire study area is now experiencing a negative change, though the amount of the net areal changes is dynamic from region to region (Table 4; Figs. 6, 7, 8, 9).

\section{Assessment on erosion hazard intensity}

The spatio-temporal changing form of erosional depositional extent along the bank line has been detected over each geomorphic unit to find out net areal changes over time. On the basis of the net areal changes erosion hazard zones has been identified (Fig. 10; Table 5). The net areal changes of different geomorphic units have postulated an important fact that the low lying coastal flat and low lying island areas have experienced massive erosion due to estuarine exposure, concentration of loose sandy materials, havoc tidal rush, extremely flat low lying topography, frequent cyclonic disturbances etc. The elevated tidal flat in the upper reaches of the estuary has shown moderate amount of net areal changes depending on channel forms, land word increase in tidal range and tidal flow directions, whereas in case of low lying tidal flat in the middle reaches of the estuary total amount of net areal change is comparatively low than the other geomorphic units due to the inner location, direction of tidal flow and nature of channel forms. The outer convex bank along the left site of the area
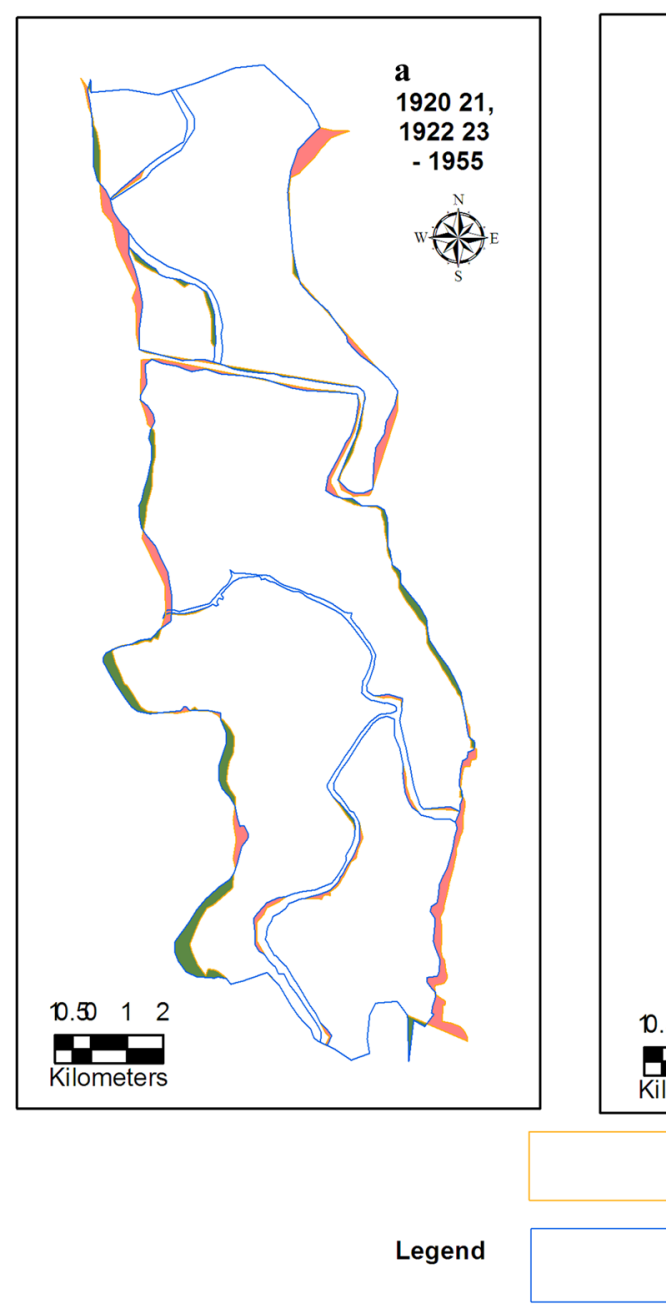

Area 1955

Area 196768,196869

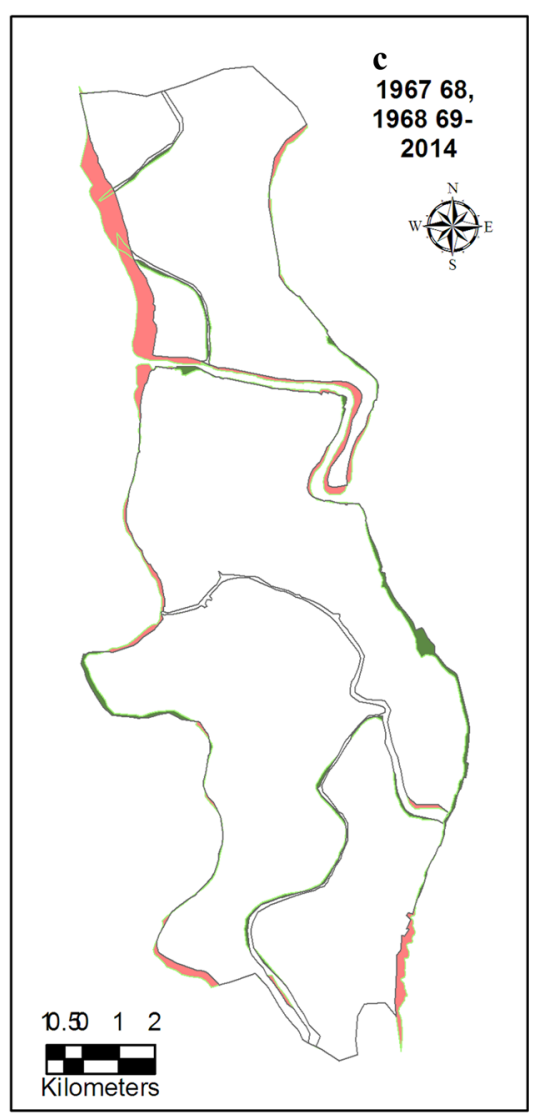

Area 2014

Eroded area

Deposited area

Fig. 8 Extent of erosion and deposition in low lying tidal flat region 

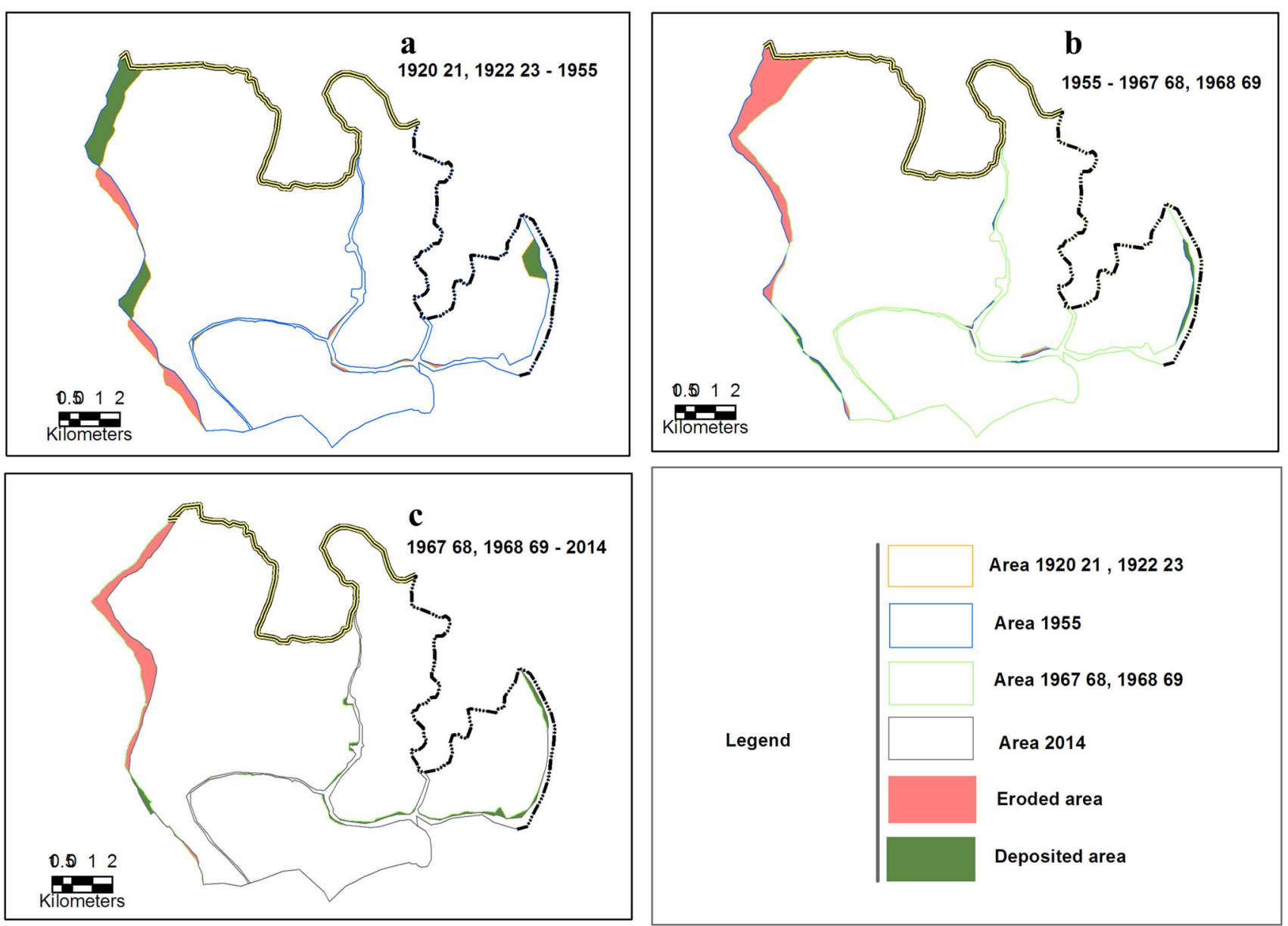

Fig. 9 Extent of erosion and deposition in elevated tidal flat region

has experienced steady erosion side by side depositional process has been active along the right site of inner concave bank.

\section{Strategic framework}

At present management of the coastal belts, deltas and estuarine environment is utmost necessary as those regions are highly susceptible to damages by frequent natural calamities and it is the homeland of million peoples (Doukakis 2005; Basu 2013; Weichselgartner and Pigeon 2015). Natural dynamics like coastal erosion, estuarine bank line alteration, rising surface temperature, changing frequencies of severe cyclonic activity, sea level change etc. have a collective manipulation on the geomorphic environment as well as on human communities in the Sundarban region. The western estuarine part of the Sundarban is one of the most vulnerable zones in this regards. Massive erosion, regressive shoreline change and progressiveness of tidal rush collectively enthrones a large confront for the Samaritans of the region. Hence structural and non structural management is needed, whereas true commitment from government and non government organization is also compulsory (Table 6).

\section{Conclusion}

The face of the Sundarban has changed successively over time due to natural and human induced reasons. The flat sandy coastal belts, deltaic estuarine low lands in the Sundarban region on the one hand have been severely affected by natural processes like long shore current, macro tidal rush, seasonal cyclonic activities, land subsidence, relative sea level rise etc. and on the other hand by anthropogenic processes like embankment construction, deforestation, immature land reclamation and bank dwellings etc. which have collectively influenced the natural 

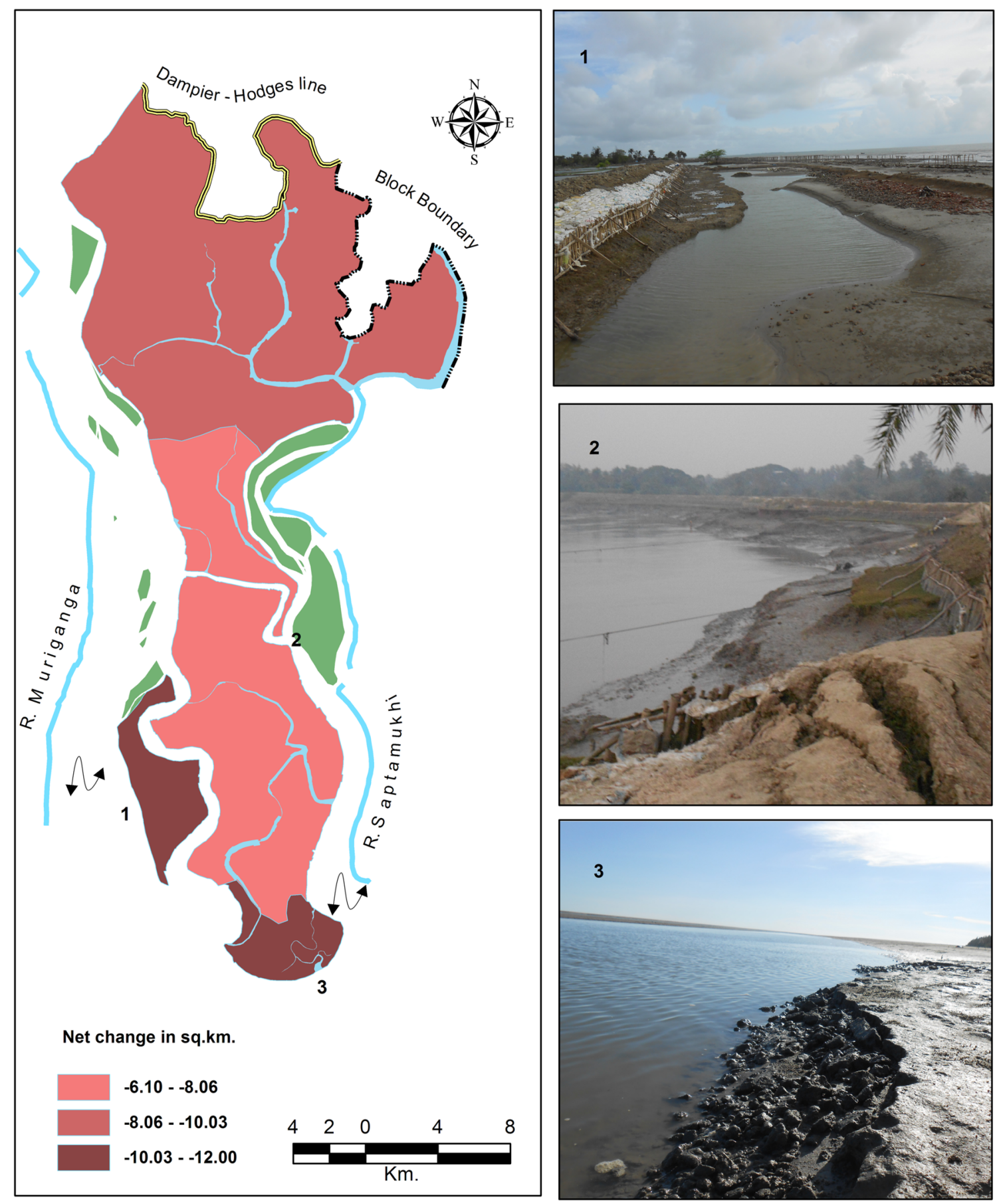

Fig. 10 Erosion hazard zones based on net areal changes over time

landscape of Sundarban region. The region especially its marginal parts have been severely affected by the erosional processes and salt water ingression. Coastal belts in the extreme southern parts, most of the low lying islands in the mouth reaches of the estuaries and exposed river banks of the Sundarban region have been severely eroded by the immense tidal bores resulting regressive changes in the morphological shape and extent of the shoreline configuration. Over time land loss becomes an important environmental crisis of this deltaic part of Sundarban region. So the currently used quantitative techniques for determining the net shoreline change, average rate of end point change 
Table 5 Net areal changes in each geomorphic unit over time

\begin{tabular}{|c|c|c|c|c|c|c|c|c|}
\hline \multirow[t]{2}{*}{ Time/area } & \multicolumn{2}{|c|}{ Low lying coastal flat } & \multicolumn{2}{|c|}{ Low lying tidal flat } & \multicolumn{2}{|c|}{ Low lying Island } & \multicolumn{2}{|c|}{ Elevated tidal flat } \\
\hline & $\begin{array}{l}\text { Erosion } \\
\text { (square } \\
\text { kilometers) }\end{array}$ & $\begin{array}{l}\text { Deposition } \\
\text { (square } \\
\text { kilometers) }\end{array}$ & $\begin{array}{l}\text { Erosion } \\
\text { (square } \\
\text { kilometers) }\end{array}$ & $\begin{array}{l}\text { Deposition } \\
\text { (square } \\
\text { kilometers) }\end{array}$ & $\begin{array}{l}\text { Erosion } \\
\text { (square } \\
\text { kilometers) }\end{array}$ & $\begin{array}{l}\text { Deposition } \\
\text { (square } \\
\text { kilometers) }\end{array}$ & $\begin{array}{l}\text { Erosion } \\
\text { (square } \\
\text { kilometers) }\end{array}$ & $\begin{array}{l}\text { Deposition } \\
\text { (square } \\
\text { kilometers) }\end{array}$ \\
\hline $\begin{array}{c}192021,1922 \\
1923-1955\end{array}$ & 3.5 & 0.5 & 6.4 & 4.3 & 4 & 0.6 & 4.4 & 7.9 \\
\hline $\begin{array}{l}\text { 1955-1967, } \\
1968, \\
1968-1969\end{array}$ & 4 & 2 & 5.8 & 5.9 & 5.1 & 1 & 9.9 & 1.6 \\
\hline $\begin{array}{l}\text { 1967-1968, } \\
1968, \\
1969-2014\end{array}$ & 5.5 & 0.1 & 7 & 2.9 & 5 & 0.5 & 6.3 & 2.4 \\
\hline Total & 13 & 2.6 & 19.2 & 13.1 & 14.1 & 2.1 & 20.6 & 11.9 \\
\hline $\begin{array}{l}\text { Net areal } \\
\text { change } \\
\text { (square } \\
\text { kilometer) }\end{array}$ & 10.4 & & 6.1 & & 12 & & 8.7 & \\
\hline
\end{tabular}

Table 6 Strategies and agencies involved for the management of natural hazards

\begin{tabular}{|c|c|c|}
\hline Areas of management & Agencies involved & $\begin{array}{l}\text { Scale of } \\
\text { impact }\end{array}$ \\
\hline $\begin{array}{l}\text { Embankment and sluice gate } \\
\text { construction }\end{array}$ & Department of irrigation and waterways, Government of West Bengal & Regional \\
\hline $\begin{array}{l}\text { Embankment management, } \\
\text { infrastructural development }\end{array}$ & $\begin{array}{l}\text { Department of irrigation and waterways Government of West Bengal, Sundarban affairs } \\
\text { department Government of West Bengal, Integrated coastal zone management plan } \\
\text { Government of West Bengal, Block Development office, village panchayets, District } \\
\text { disaster management Committee }\end{array}$ & Regional \\
\hline Conservation of forest resource & $\begin{array}{l}\text { Sundarban affairs department, Integrated coastal zone management plan Government of } \\
\text { West Bengal, Block Development office, village panchayets }\end{array}$ & Regional \\
\hline $\begin{array}{l}\text { Monitoring the bathymetric } \\
\text { condition of the estuary }\end{array}$ & Kolkata Port Trust. Marine Department & Regional \\
\hline $\begin{array}{l}\text { Conciseness, education and } \\
\text { campaigning }\end{array}$ & $\begin{array}{l}\text { Sundarban affairs department Government of West Bengal, Integrated coastal zone } \\
\text { management plan Government of West Bengal, Block Development office, village } \\
\text { panchayets, District disaster management Committee }\end{array}$ & $\begin{array}{l}\text { Local to } \\
\text { regional }\end{array}$ \\
\hline $\begin{array}{l}\text { Monitoring climatic conditions and } \\
\text { tide }\end{array}$ & Regional meteorological centre, Alipore Kolkata. Kolkata Port Trust. Marine Department & Regional \\
\hline
\end{tabular}

and net areal change can well be applied in other parts of Sundarban region. Consequently proper coastal zone management strategies can be fruitfully implemented.

\section{References}

Addo KA (2015) Assessment of the Volta delta shoreline change. J Coast Zone Manag 18(3):1-6. doi:10.4172/jczm. 1000408

Alam M, Alam MM, Curray JR, Chowdhury MLR, Gani MR (2003) An overview of the sedimentary geology of the Bengal Basin in relation to the regional tectonic framework and basin-fill history. Sed Geol 155:179-208

Bandyopadhyay S (1997) Natural environmental hazard and their management case study of Sagar Island India. Singap J Trop Geogr 18:20-25. doi:10.1111/1467-9493.00003
Bandyopadhyay S (2007) Evolution of the Ganga Brahmaputra delta: a review. Geogr Rev India 69(3):235-268

Bandyopadhyay S, Bandyopadhyay MK (1996) Restrogradation of the Western Ganga-Brahmaputra Delta (India and Bangladesh): possible reasons. Natl Geogr 31(Nos. 1 \& 2):105-128

Bandyopadhyay S, Nandy S (2011) Trends of sea level rise in Hugli estuary, India. Indian J Geomarine Sci 40:802-812

Bandyopadhyay S, Mukherjee D, Bag S, Pal DK, Rudra K (2004) 20th Century Evolution of Banks and Islands of the Hugli estuary. In: Singh S, Sharma HS, De SK (eds) West Bengal, India: Evidence from Maps, Images and GPS Survey, Geomorphology and environment. ACB Publications, Kolkata, pp 235-263

Bandyopadhyay J, Mondal I, Samanta N (2014) Shore line shifting of Namkhana Island of Indian Sundarban, South 24 Parganas, West Bengal, India. Using Remote Sens GIS Tech Int J Eng Sci Res Technol 3(5):162-169

Basu R (2013) Constraints of biodiversity conservation in the Fragile ecosystems: the case of Sundarban Region in Ganga Delta of 
India. SIJ Trans Adv Space Res Earth Explor (ASREE) 1(1):26-31

Chakrabarti P (1995) Evolutionary history of the coastal quaternaries of the Bengal plain, India. In: Proceedings of Indian National Science Academy, 61A (no 5):343-354

Chakraborty S (2013) Delineation of morpho-structural changes of some selected islands in the Ganga delta region, West Bengal, India: a spatio-temporal change detection analysis using GIS and Remote sensing. Int J Sci Nat 4(3):499-507

Danda A, Anurag A, Sriskanthan G, Ghosh A, Bandyopadhyay J, Hazra S (2011) Indian Sundarbans Delta: a vision. World Wide Fund for Nature-India, New Delhi, pp 1-40

Das GK (2006) Sunderbans environment and ecosystem. Sarat Book Distributors, Kolkata, pp 30-73

Das S, Choudhury MR, Das S, Khan S (2013) Monitoring shore line and Inland changes by using multi-temporal satellite data and risk assessment: a case study of Ghoramara Island, West Bengal. Int J Geosci Technol 1(1):1-20

Doukakis E (2005) Coastal vulnerability and risk parameters. Eur Water 11(12):3-7

Ghosh A (2012) Living with changing climate Impact, vulnerability and adaptation challenges in Indian Sundarbans. In: Chaudhuri J (ed) Centre for Science and Environment, New Delhi, p 91

Goodbred SL Jr, Kuehl SA, Steckler MS, Sarker MH (2003) Controls on facies distribution and stratigraphic preservation in the Ganges-Brahmaputra delta sequence. Sed Geol 155:301-316

Hazra S, Samanta K, Mukhopadhyay A, Akhand A (2010) Temporal change detection (2001-2008) study of Sundarban (final report). School of Oceanographic Studies, Jadavpur University, Jadavpur

Hossain MS, Dearing JA, Rahaman MM, Salehin M (2015) Recent changes in ecosystem services and human well-being in the Bangladesh coastal zone. Reg Environ Chang 16:429-443. doi:10.1007/s10113-014-0748-z

Islam SN, Gnauck A (2008) Mangrove wetland ecosystems in Ganges-Brahmaputra delta in Bangladesh. Front Earth Sci China 2(4):439-448. doi:10.1007/s11707-008-0049-2

Islam MR, Begum SF, Yamaguchi Y, Ogawa K (1999) The Ganges and Brahmaputra rivers in Bangladesh: basin denudation and sedimentation. Hydrol Process 13:2907-2923

Jana A, Sheena S, Biswas A (2012) Morphological change study of Ghoramara Island, Eastern India using multi temporal satellite data. Res J Recent Sci 1(10):72-81

Jha VC, Bairagya HP (2011) Flood plain evaluation in the GangaBrahmaputra delta: a tectonic review. Ethiop J Environ Stud Manag 4(3):12-24. doi:10.4314/ejesm.v4i3.3

Laha C, Bandyopadhyay S (2013) Analysis of the changing morphometry of River Ganga, shift monitoring and vulnerability analysis using space-borne techniques: a statistical approach. Int J Sci Res Publ 3:1-10

Mallick B, Vogt J (2015) Societal dealings with cyclone in Bangladesh: a proposal of vulnerability atlas for sustainable disaster risk reduction. J Coast Zone Manag 18(3):1-11. doi:10. 4172/jczm. 1000409

Mandal RN, Das CS, Naskar KR (2009) Dwindling Indian Sundarban Mangrove: the Way Out. Sci Cult 76(7-8):275-282

Mikhailov VN, Dotsenko MA (2007) Processes of delta formation in the mouth area of the Ganges and Brahmaputra Rivers. Hydrol Process 34(4):385-400. doi:10.1134/S0097807807040033

Misra A, Balaji R (2015) A study on the shoreline changes and Landuse/land-cover along the South Gujarat coastline. Proc Eng 116:381-389. doi:10.1016/j.proeng.2015.08.311

Mukherjee KN (2002) Sundarban histogenesis, hazards and nemeses, changing environmental scenario of the Indian Sundarban. ACB Publication, Kolkata, pp 263-280

Paul AK (2002) Coastal geomorphology and environment: Sundarban coastal plain, Kathi coastal plain, Subarnarekha delta plain. ACB Publications, Kolkata, pp 131-559

Rahman MM (2012) Time-series analysis of coastal erosion in the Sundarbans mangrove, international archives of the photogrammetry. Remote Sens Spatial Inf Sci 39(B8):425-429

Raju DK, Santosh K, Chandrasekar J, Tiong-Sa T (2010) Coastline change measurement and generating risk map for the coast using geographic information system. Int Arch Photogram Remote Sens Spatial Inf Sci 38(part II):492-497

Rudra K (2012) The atlas of the changing river courses in West Bengal. Sea Explorers' Institute (SEI), Kolkata

Sarkar A, Sengupta S, McArthur JM, Ravenscroft P, Bera MK, Bhushan R, Samanta A, Agrawal S (2009) Evolution of GangesBrahmaputra western delta plain: clues from sedimentogoly and carbon isotopes. Quat Sci Rev 28:2564-2581. doi:10.1016/j. quascirev.2009.05.016

Stanley DJ, Hait AK (2000) Holocene depositional patterns, neotectonics and sundarban mangroves in the Western GangesBrahmaputra delta. J Coastal Res 16(1):26-39

Tsoukala VK, Katsardi V, Hadjibiros K, Moutzouris CI (2015) Beach erosion and consequential impacts due to the presence of Harbours in sandy beaches in Greece and Cyprus. Environ Process (Suppl 1):55-71. doi: 10.1007/s40710-015-0096-0

Udo-Akuaibit SP (2014) Morpho-dynamics shoreline offset at the entrance of Qua Iboe River Estuary, South East Coast of Nigeria. J Coast Dev 17(391):1-8. doi:10.4172/1410-5217.1000391

Weichselgartner J, Pigeon P (2015) The role of knowledge in disaster risk reduction. Int J Disaster Risk Sci 6:107-116. doi:10.1007/ s13753-015-0052-7 